\title{
Implementation of Fuzzy Multi-Objective Optimization On The Basic Of Ratio Analysis (Fuzzy-MOORA) In Determining The Eligibility Of Employee Salary (Case Study: CV. Harmoni Permata)
}

Implementasi Fuzzy Multi-Objective Optimization On The Basic Of Ratio Analysis (FuzzyMOORA) Dalam Penentuan Kelayakan Bonus Gaji Karyawan (Studi Kasus: CV. Harmoni Permata)

\section{Gede Iwan Sudipa ${ }^{*}$, I Nyoman Tri Anindia Putra², Dwi Putra Asana ${ }^{3}$, Revan Dwi Hanza $^{4}$}

1,2,3,4 Teknik Informatika, STMIK STIKOM Indonesia, Indonesia

1*iwansudipa@stiki-indonesia.ac.id, 2trianindiaputra@stiki-indonesia.ac.id,

33wiputraasana@stiki-indonesia.ac.id, ${ }^{4}$ iamrepan@gmail.com

*: Penulis korespondensi (corresponding author)

\section{Informasi Artikel}

Received: April 2021

Revised: June 2021

Accepted: June 2021

Published: August 2021

\begin{abstract}
Purpose: CV. Harmoni Permata has several employees, and each employee has a salary bonus. The process of determining which employees are eligible for employee salary bonuses in $\mathrm{CV}$. Harmoni Permata is still done by manual assessment. This assessment causes errors in calculations because the decision-maker must look at previous historical data to decide the best employees.

Design/methodology/approach: System design includes a system that can manage user data, job data, criteria data, criteria description data, attendance data, task data, and assessment data. These data will later produce an assessment report. The MOORA method approach is used because it has minimum and simple math calculations and has a good level of alternative selectivity.

Findings/result: The normalization test for comparison of manual calculations using the MOORA method with the results of system calculations is the same. The five best alternative employees deserve to receive salary bonuses.

Originality/value/state of the art: Based on a review of previous research, this study uses the criteria of performance, honesty, attendance and accuracy by determining the weights based on the nature of benefits or costs and the MOORA method in calculating the final value of alternative rankings.
\end{abstract}


Keywords:Decision Making; Employee

Salary Bonuses; Fuzzy MOORA

Kata kunci: Penentuan Keputusan,

Bonus Gaji Karyawan, Fuzzy MOORA

\begin{abstract}
Abstrak
Tujuan: CV. Harmoni Permata memiliki beberapa karyawan dan masing-masing karyawan memiliki bonus gaji. Proses menentukan karyawan yang layak mendapatkan bonus gaji karyawan di CV. Harmoni Permata masih dilakukan dengan penilaian manual. Penilaian ini menyebabkan kesalahan dalam perhitungan karena pengambil keputusan harus melihat data histori sebelumnya untuk menghasilkan keputusan karyawan terbaik.
\end{abstract}

Perancangan/metode/pendekatan: Perancangan Sistem meliputi sistem yang dapat mengelola data user, data jabatan, data kriteria, data keterangan kriteria, data presensi, data task, dan data penilaian. Data-data tersebut nantinya akan menghasilkan laporan penilaian. Pendekatan Metode MOORA digunakan karena memiliki perhitungan dengan kalkulasi yang minimum dan sederhana serta memiliki tingkat selektifitas alternatif yang baik.

Hasil: Pengujian normalisasi perbandingan perhitungan manual metode MOORA dengan hasil perhitungan sistem adalah sama, dengan 5 alternatif karyawan terbaik yang layak menerima bonus gaji.

Keaslian/ state of the art: Berdasarkan tinjauan penelitian terdahulu maka dalam penelitian ini menggunakan kriteria kinerja, kejujuran, absensi dan ketelitian dengan penentuan bobot berdasarkan sifat benefit atau cost serta metode MOORA dalam perhitungan nilai akhir perankingan alternatif.

\section{Pendahuluan}

Banyak perusahaan memberikan bonus gaji kepada karyawan atau pegawainya. Bonus gaji tersebut digunakan untuk reward atau suatu pencapaian oleh karyawan atas kinerjanya[1]. Tentunya pemberian bonus gaji tersebut sangat mempengaruhi kinerja karyawan atau pegawai, sebab bonus gaji tersebut dapat memberikan motivasi untuk para karyawan atau pegawai untuk bekerja lebih giat lagi[2],[3]. Perusahaan juga perlu mempertimbangkan kelayakan pemberian bonus gaji kepada karyawan atau pegawainya, ini dikarenakan perusahaan memberikan bonus gaji berdasarkan kinerja karyawan atau pegawainya. Setiap karyawan atau pegawai dalam sebuah perusahaan tentunya mendapat besaran bonus gaji yang berbeda-beda. CV. Harmoni Permata adalah perusahaan yang bergerak di bidang IT (Information Technology) atau yang sering disebut dengan teknologi informasi. Pada CV. Harmoni Permata menentukan kelayakan bonus gaji berdasarkan kriteria task atau kinerja, absensi, ketelitian, dan kejujuran. Proses pemberian bonus dilakukan 3 bulan sekali, Biasanya karyawan CV. Harmoni Permata mengumpulkan laporan kinerjanya satu minggu sekali, kemudian HRD merekap hasil tersebut menjadi satu file untuk laporan perminggu. Maka selama sebulan file yang dibuat adalah 4 file,. 
CV. Harmoni Permata memberikan bonus gaji 3 bulan sekali sehingga ada 12 file yang harus dilihat oleh HRD, hal ini akan menyebabkan penumpukan arsip dan HRD harus menyeleksi file untuk menentukan siapa karyawan yang layak mendapatkan bonus gaji. Terdapat juga kendala ketika banyaknya task atau kinerja yang dikerjakan oleh karyawan sering terjadinya konflik, dimana tugas yang sebelumnya sudah terselesaikan oleh karyawan A dikerjakan lagi oleh karyawan B. Kesalahan tersebut sangat mempengaruhi dalam penentuan bonus gaji karena dapat merugikan perusahaan, dimana yang seharunya memberikan bonus gaji untuk satu karyawan saja jika terjadi kesalahan tersebut maka perusahaan harus memberikan bonus gaji ke karyawan lain dengan tugas yang seharusnya sudah terselesaikan. Selain itu ketika ingin menentukan kelayakan pemberian bonus gaji maka pihak yang memberi keputusan dalam penentuan kelayakan harus melakukan pengecekan ulang dari data-data sebelumnya, serta dari segi transparansi data pada penentuan kelayakan bonus gajinya terbilang kurang terbuka[4], sehingga karyawan tidak mengetahui alasan mengapa tidak layak mendapatkan bonus.

Penjelasan permasalahan diatas menjadi landasan dalam penelitian ini bahwa dalam proses seleksi yang dilakukan tidak terdapat transparansi dalam proses penilaian sangat mempengaruhi hasil keputusan[5]. Beberapa penelitian terdahulu mengenai penentuan karyawan terbaik dalam kaitan dengan penentuan bonus karyawan [4],[1] pada penelitian ini menggunakan kriteria kehadiran, pelayanan, ketaatan, sikap kerjasama, dan sikap dalam mengontrol emosi. Metode Analytical Hierachy Process (AHP) dan Analytical Network Process (ANP) digunakan untuk menentukan bobot kriteria, serta penilaian atribut kriteria menggunakan Behaviorally Anchor Rating Scale (BARS). Penelitian yang menggunakan metode MOORA yaitu dalam menentukan engineer yang memperoleh bonus[6] dalam penelitian ini menggunakan 5 kriteria dengan optimalisasi atribut berdasarkan sifat kriteria dan penilaian atribut dengan rating scale. Selanjutnya penelitian[7] dalam penyelesaian kelayakan penerima bantuan. Penelitian yang membuktikan efektifitas perhitungan metode MOORA[8]. Penelitian tentang kombinasi Fuzzy - MOORA[9] untuk penentuan sektor industri, pada penelitian ini menggunakan teori himpunan fuzzy dalam nilai atribut. Penelitian yang menerangkan kombinasi Fuzzy-MOORA dapat mengatasi permasalahan ketidakjelasan, ketidaklengkapan informasi serta faktor kuantitatif dan kualitatif dari kriteria penilaian[10].

\section{Metode/Perancangan}

Terdapat model Sistem Pendukung Keputusan (SPK) pada penelitian ini yang ditujukan untuk mengetahui fungsionalitas metode yang digunakan[11], pada penelitian ini menggunakan metode Fuzzy-MOORA dalam menyelesaikan permasalahan penentuan kelayakan bonus gaji karyawan. Adapun gambaran umum model dapat dilihat pada Gambar 1 sebagai berikut: 


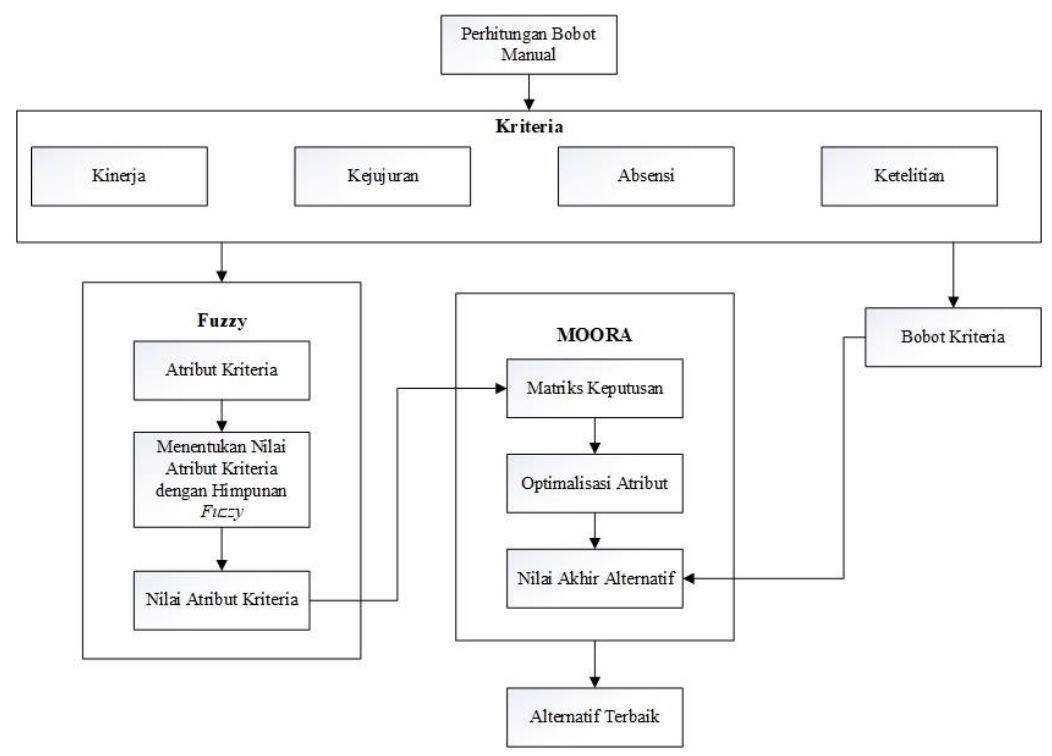

Gambar 1. Gambaran Umum Model SPK Penentuan Kelayakan Bonus Gaji Karyawan

Merujuk kepada Gambar 1 dapat dijelaskan bahwa bobot kriteria dihitung dengan perhitungan bobot dengan interval [0-100\%] oleh pengambil keputusan, nilai bobot kriteria yang dihasilkan pada proses selanjutnya digunakan untuk menghitung nilai akhir alternatif pada proses metode MOORA. Metode Fuzzy digunakan untuk menentukan nilai setiap atribut kriteria dengan fungsi keanggotaan, dan selanjutnya nilai atribut kriteria digunakan dalam proses matriks keputusan pada metode MOORA. Proses penentuan alternatif terbaik diperoleh dari perhitungan pada proses metode MOORA.

\subsection{Teori Himpunan Fuzzy}

Teori himpunan fuzzy dapat digunakan untuk memodelkan sistem yang sulit untuk didefinisikan secara tepat karena ketidak jelasan dan ketidakpastian dalam persepsi manusia[12], ketidakjelasan dan ketidakpastian ini dapat dimodelkan dengan fungsi keanggotaan[13]. Fungsi derajat keanggotaan sangat mempengaruhi teori himpunan fuzzy[14]. Salah satu cara yang dapat digunakan untuk menentukan nilai keanggotaan adalah melalui pendekatan fungsi representasi kurva, antara lain kurva linier, kurva segitiga, kurva trapesium, kurva bentuk bahu, kurva S, kurva bentul lonceng serta kurva Gauss[3],[15]. Adapun contoh representasi kurva bentuk bahu[16], dapat dilihat pada Gambar 2 berikut:

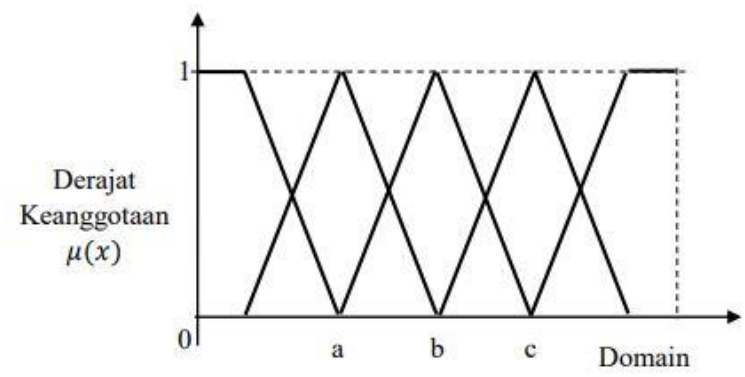

Gambar 2. Representasi Kurva Bentuk Bahu 
Fungsi keanggotaan yang merepresentasikan kurva bahu kiri diperlihatkan pada persamaan (1), berikut:

$$
\mu(x)=\left\{\begin{array}{rc}
1 ; & x \leq a \\
\frac{(b-x)}{(b-a)} ; & a \leq x \leq b \\
0 ; & x \geq b
\end{array}\right\}
$$

Fungsi keanggotaan yang merepresentasikan kurva bahu kanan diperlihatkan pada persamaan (2), berikut:

$$
\mu(x)=\left\{\begin{array}{rc}
0 ; & x \leq b \\
\frac{(x-b)}{(c-b)} ; & b \leq x \leq c \\
1 ; & x \geq c
\end{array}\right\}
$$

Keterangan:

$\mu(x)$ adalah derajat keanggotaan

a,b,c adalah domain

\subsection{Multi Objective Optimalization On The Base Of Ratio Analysis (MOORA)}

MOORA merupakan salah satu metode Fuzzy Multi Criteria Decision Making (FMCDM) yang digunakan untuk menyelesaikan masalah yang berkaitan dengan keputusan dan perencanaan menggunakan beberapa kriteria yang saling bertentangan[17]. Di antara kriteria yang bertentangan ini, beberapa di antaranya memiliki sifat cost atau benefit. Proses analisis rasio pada metode MOORA merupakan proses pengoptimalan dua atau lebih banyak atribut evaluasi yang saling bertentangan secara bersamaan serta mempertimbangkan sifat kriteria untuk menentukan peringkat dari alternatif terbaik. Tahapan dalam metode MOORA, antara lain[9],[18]:

\section{a. Menentukan Identifikasi Atribut Evaluasi dan Rating Kecocokan Alternatif pada Setiap Kriteria}

Pada tahap awal adalah menentukan tujuan dan mengidentifikasi nilai atribut evaluasi serta membuat rating kecocokan nilai alternatif ke-m terhadap setiap kriteria.

\section{b. Membuat Matriks Keputusan X}

Tahap selanjutnya yaitu menampilkan informasi dari atribut dalam bentuk matriks keputusan $(X)$ dapat diperlihatkan pada persamaan (3), berikut:

$$
X=\begin{gathered}
A_{1} \\
A_{2} \\
\cdot \\
\cdot \\
A_{m}
\end{gathered}\left[\begin{array}{cccc}
X_{11} & X_{12} & \ldots & X_{1 n} \\
X_{21} & X_{21} & \ldots & X_{2 n} \\
\cdot & \cdot & \cdot & \cdot \\
\cdot & \cdot & \cdot & \cdot \\
X_{m 1} & X_{m 2} & \cdot & X_{m n}
\end{array}\right]
$$

Keterangan:

$X$ merupakan matriks keputusan $X$

$A_{m}$ merupakan alternatif ke -m

$\mathrm{x}_{\mathrm{m} 1}$ merupakan rating kinerja alternatif ke $-\mathrm{m}$ terhadap atribut ke-i. 


\section{c. Menentukan Matriks Normalisasi}

Matriks ternormalisasi ditunjukkan dengan matrik Xij atau bisa disebut rasio Xij yang menunjukkan nilai normalisasi untuk tiap kriteria $\mathrm{n}$ dari setiap alternatif $\mathrm{m}$. Normalisasi dilakukan dengan menentukan nilai akar kuadrat dari jumlah kuadrat penjumlahan setiap nilai alternatif setiap atribut. Perhitungan matriks normalisasi diperlihatkan pada persamaan (4), berikut:

$$
X^{*} i j=\frac{X i j}{\sqrt{\left[\sum_{i=1}^{m} x^{2} i j(j=1,2, \ldots n)\right]}}
$$

\section{Keterangan:}

xij adalah Matriks dalam interval $[0,1]$ yang menunjukkan kinerja ternormalisasi dari alternatif j pada kriteria $i$.

$\mathrm{i}: 1,2,3, \ldots, \mathrm{n}$ adalah nomor urutan atribut atau kriteria

$\mathrm{j}: 1,2,3, \ldots, \mathrm{m}$ adalah nomor urutan alternatif

$X^{*} i j$ : Matriks Normalisasi alternatif j pada kriteria

\section{d. Optimalisasi Atribut}

Pada tahap ini terdapat proses optimalisasi multi-objektif, yang dimaksudkan bahwa setiap kinerja atribut yang sudah dinormalisasi selanjutnya akan dimaksimalisasi (apabila atribut benefit) dan dikurangi jika diminimalkan (atribut cost) atau mengurangi niali maksimum dan minimum pada setiap baris untuk mendapatkan ranking pada setiap baris. Perhitungan optimalisasi atribut diperlihatkan pada persamaan (5), berikut:

$$
Y^{i}=\sum_{j=1}^{g} X^{*} i j-\sum_{j=g+1}^{n} X^{*} i j
$$

Keterangan:

$g$ : jumlah atribut yang dimaksimalkan

$(n-g)$ adalah jumlah atribut yang diminimalkan

$Y i$ adalah nilai penilaian yang telah dinormalisasi dari alternatif ke-n terhadap semua atribut.

\section{e. Menentukan Nilai Akhir Perankingan Alternatif}

Apabila nilai optimalisasi atribut sudah diperoleh, maka untuk menghitung nilai akhir dilakukan perkalian nilai optimalisasi atribut dengan nilai bobot setiap atribut. Perhitungan nilai akhir perankingan alternatif diperlihatkan pada persamaan (6), berikut:

$$
Y^{i}=\sum_{j=1}^{g} W j X^{*} i j-\sum_{j=g+1}^{n} W j X^{*} i j
$$

Keterangan:

$Y^{i}$ adalah nilai penilaian normalisasi alternatif $i$ terhadap semua atribut

$W j$ adalah bobot terhadap $j$

$X^{*} i j$ menunjukkan urutan ke $-i$ dari alternatif pada kriteria ke $-j$

\subsection{Pengumpulan Data}

Teknik pengumpulan data dalam penelitian ini terdiri dari observasi, dokumentasi, wawancara dan studi pustaka. Berdasarkan dari proses observasi ke lokasi penelitian, dan wawancara dengan Bapak Reno Sacino selaku HRD di CV. Harmoni Permata, maka diperoleh data karyawan selama periode Bulan Januari - Maret 2020. Data karyawan digunakan sebagai data alternatif, dapat dilihat pada Tabel 1 berikut: 
Tabel 1. Data Alternatif Karyawan

\begin{tabular}{llll} 
No. & Kode Alternatif & Nama Karyawan & Posisi \\
\hline 1. & A1 & Wawan & UI/UX Programmer \\
\hline 2. & A2 & Revan & Back-End Programmer \\
\hline 3. & A3 & Arda & Back-End Programmer \\
\hline 4. & A4 & Surya & Front End Programmer \\
\hline 5. & A5 & Galih & Tester \\
\hline
\end{tabular}

Adapun dalam penentuan kelayakan bonus gaji karyawan terdapat beberapa kriteria yang digunakan sebagai bahan pertimbangan pengambil keputusan. Kriteria terdiri dari Kinerja (C1), Kejujuran (C2), Absensi (C3) dan Ketelitian (C3). Data kriteria penilaian dapat dilihat pada Tabel 2, sebagai berikut:

Tabel 2. Data Kriteria

\begin{tabular}{|l|l|l|}
\hline No. & Kode Kriteria & Nama Kriteria \\
\hline 1. & C1 & Kinerja \\
\hline 2. & C2 & Kejujuran \\
\hline 3. & C3 & Absensi \\
\hline 4. & C4 & Ketelitian \\
\hline
\end{tabular}

\section{Hasil dan Pembahasan}

\subsection{Analisa Data Kriteria}

Pada tahap awal proses perhitungan metode MOORA diperlukan analisa kriteria yang terdiri dari nilai bobot kriteria serta sifat dari kriteria, analisa ini diperlukan untuk mengetahui terdapat kriteria yang saling bertentangan. Merujuk kepada Gambar 2, maka penentuan bobot kriteria ditentukan dengan interval nilai [0-100\%]. Untuk menentukan sifat kriteria dilihat dari nilai yang akan diinputkan, apabila nilai semakin besar atau dimaksimalkan semakin baik maka termasuk sifat benefit, sedangkan nilai yang semakin kecil atau diminalkan semakin baik maka termasuk sifat cost. Analisa data kriteria dapat dilihat pada Tabel 3 berikut:

Tabel 3. Analisa Data Kriteria

\begin{tabular}{lllll} 
No. & Kode Kriteria & Nama Kriteria & Bobot & Sifat Kriteria \\
\hline 1. & C1 & Kinerja & 0,35 & Benefit \\
\hline 2. & C2 & Kejujuran & 0,30 & Benefit \\
\hline 3. & C 3 & Absensi & 0,15 & Benefit \\
\hline 4. & C4 & Ketelitian & 0,20 & Benefit \\
\hline
\end{tabular}

\subsection{Fungsi Keanggotaan Atribut Kriteria}

Setiap kriteria penilaian akan dibagi menjadi beberapa atribut, untuk menghindari ketidakjelasan penilaian dari setiap kriteria maka untuk menentukan nilai atribut digunakan fungsi keanggotaan fuzzy. Fungsi keanggotaan direpresentasikan menggunakan kurva bentuk bahu, dari kurva ini dapat diketahui nilai serta kategori keterangan yang digunakan dalam penilaian alternatif pada setiap kriteria. Adapaun kategori keterangan yang dihasilkan yaitu Sangat Buruk dengan interval nilai [0-10], Buruk dengan interval nilai [11-20], Cukup dengan interval nilai [21-30], Baik dengan interval nilai [31-40], Cukup Baik dengan interval nilai [41- 
50], dan Sangat Baik dengan interval nilai [ $>50$ ]. Representasi kurva dapat dilihat pada Gambar 3 berikut:

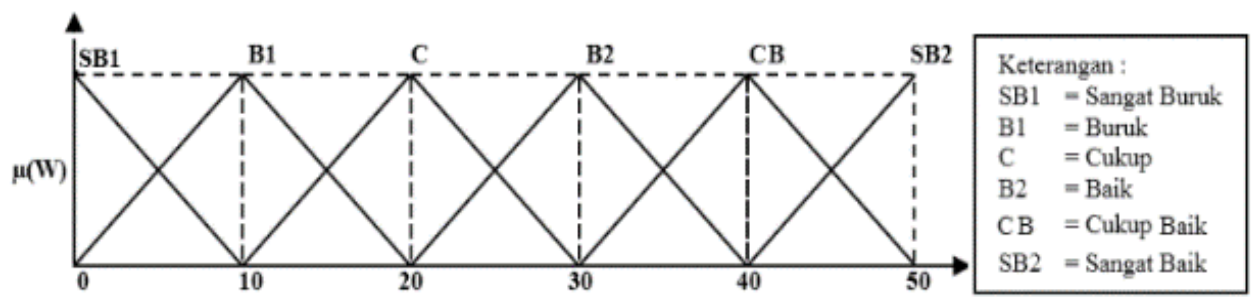

Gambar 3. Representasi Kurva Bentuk Bahu untuk Atribut Kriteria

\subsection{Identifikasi Nilai Atribut Evaluasi}

Berdasarkan dari proses sebelumnya maka pada identifikasi nilai atribut evaluasi, setiap kriteria memiliki atribut agar memudahkan dalam menentukan interval nilai alternatif pada setiap kriteria. Fungsi keanggotaan dari fuzzy digunakan untuk menjelaskan setiap interval nilai dari setiap atribut. Pada kriteria Kinerja (C1) terdapat atribut jumlah kinerja dilakukan karyawan selama 3 bulan, jumlah kinerja dihitung total per jam. Nilai atribut untuk kriteria Kinerja (C1) dapat dilihat pada Tabel 4, berikut:

Tabel 4. Nilai Atribut Kriteria Kinerja

\begin{tabular}{llll} 
No. & $\begin{array}{l}\text { Atribut } \\
\text { (dalam satuan } \\
\text { jam) }\end{array}$ & Interval Nilai & $\begin{array}{l}\text { Fungsi } \\
\text { Keanggotaan }\end{array}$ \\
\hline 1. & $0-32$ & $11-20$ & Buruk \\
\hline 2. & $33-64$ & $21-30$ & Cukup \\
\hline 3. & $65-96$ & $31-40$ & Baik \\
\hline 4. & $97-128$ & $41-50$ & Cukup Baik \\
\hline 5. & $128-160$ & $>50$ & Sangat Baik \\
\hline
\end{tabular}

Pada kriteria Kejujuran (C2) terdapat atribut yang menerangkan attitude karyawan dalam menyelesaikan task atau pekerjaan yang diberikan. Nilai atribut untuk kriteria Kejujuran (C2) dapat dilihat pada Tabel 5, berikut:

Tabel 5. Nilai Atribut Kriteria Kejujuran

\begin{tabular}{llll} 
No. & Atribut & Interval Nilai & $\begin{array}{l}\text { Fungsi } \\
\text { Keanggotaan }\end{array}$ \\
\hline 1. & $\begin{array}{l}\text { Mengambil } \\
\text { Task Teman }\end{array}$ & 0-10 & Buruk \\
\cline { 2 - 2 } & Berkata Bohong & \\
\hline 2. & $\begin{array}{l}\text { Tidak berkata } \\
\text { bohong A }\end{array}$ & Sangat Baik \\
& $\begin{array}{l}\text { Bicara Apa } \\
\text { adanya }\end{array}$ & \\
\hline
\end{tabular}

Pada kriteria Absensi (C3) terdapat atribut persentase kehadiran karyawan. Nilai atribut untuk kriteria Absensi (C3) dapat dilihat pada Tabel 6, berikut: 
Tabel 6. Nilai Atribut Kriteria Absensi

\begin{tabular}{llll} 
No. & $\begin{array}{l}\text { Atribut } \\
\text { (dalam satuan } \\
\text { \%) }\end{array}$ & Interval Nilai & $\begin{array}{l}\text { Fungsi } \\
\text { Keanggotaan }\end{array}$ \\
\hline 1. & $0-30$ & $31-40$ & Baik \\
\hline 2. & $31-60$ & $41-50$ & Cukup Baik \\
\hline 3. & $61-100$ & $>50$ & Sangat Baik \\
\hline
\end{tabular}

Pada kriteria Ketelitian (C4) terdapat atribut ketelitian karyawan dalam menyelesaikan task yang diberikan. Nilai atribut untuk kriteria Ketelitian (C4) dapat dilihat pada Tabel 7, berikut:

Tabel 7. Nilai Atribut Kriteria Ketelitian

\begin{tabular}{llll} 
No. & Atribut & Interval Nilai & $\begin{array}{l}\text { Fungsi } \\
\text { Keanggotaan }\end{array}$ \\
\hline 1. & Bugs Task $>16$ & $31-40$ & Baik \\
\hline 2. & Bugs Task $6-10$ & $41-50$ & Cukup Baik \\
\hline 3. & Bugs Task $10-15$ & $41-50$ & Cukup Baik \\
\hline 4 & Bugs Task $1-5$ & $>50$ & Sangat Baik \\
\hline 5 & Tidak ada Bugs & $>50$ & Sangat Baik \\
\hline
\end{tabular}

\subsection{Rating Kecocokan Alternatif pada Setiap Kriteria}

Pada tahap ini setiap alternatif diberikan nilai berdasarkan dari kriteria penilaian, nilai yang diberikan oleh pengambil keputusan dilihat dari progress karyawan selama 3 bulan. Inputan nilai yang diberikan disesuaikan dengan nilai interval fungsi keanggotaan pada proses identifikasi nilai atribut evaluasi. Keterangan optimum menunjukkan sifat dari setiap kriteria merujuk kepada Tabel 3, karena semua kriteria bersifat benefit maka keterangan optimal adalah Max atau nilai dimaksimalkan semakin baik. Nilai alternatif pada setiap kriteria dapat dilihat pada Tabel 8, berikut:

Tabel 8. Nilai Alternatif Pada Setiap Kriteria

\begin{tabular}{lllll} 
Kode Alternatif & $\begin{array}{l}\text { Kinerja } \\
(\mathbf{C} 1)\end{array}$ & $\begin{array}{l}\text { Kejujuran } \\
(\mathbf{C 2})\end{array}$ & $\begin{array}{l}\text { Absensi } \\
(\mathbf{C 3})\end{array}$ & $\begin{array}{l}\text { Ketelitian } \\
(\mathbf{C 4})\end{array}$ \\
\hline A1 & 50 & 50 & 40 & 40 \\
\hline A2 & 30 & 50 & 40 & 50 \\
\hline A3 & 30 & 50 & 30 & 50 \\
\hline A4 & 40 & 50 & 40 & 40 \\
\hline A5 & 40 & 50 & 50 & 30 \\
\hline Optimum & Max & Max & Max & Max \\
\hline
\end{tabular}

\subsection{Matriks Keputusan $X$}

Merujuk dari Tabel 8, selanjutnya dibuat matriks keputusan X yang menunjukkan rating kinerja (X) alternatif pada setiap kriteria merujuk kepada Persamaan (3), sebagai berikut: 


$$
X=\left[\begin{array}{llll}
50 & 50 & 40 & 40 \\
30 & 50 & 40 & 50 \\
30 & 50 & 30 & 50 \\
40 & 50 & 40 & 40 \\
40 & 50 & 50 & 30
\end{array}\right]
$$

\subsection{Matriks Normalisasi}

Normalisasi matriks untuk setiap kriteria merujuk kepada Persamaan (4).

- Normalisasi matriks kriteria Kinerja (C1)

$$
\begin{aligned}
C 1 & =\sqrt{50^{2}+30^{2}+30^{2}+40^{2}+40^{2}} \\
& =86,60
\end{aligned}
$$

$\mathrm{A} 11=50 / 86,60=0,577$

$\mathrm{A} 21=30 / 86,60=0,346$

$\mathrm{A} 31=30 / 86,60=0,346$

$\mathrm{A} 41=40 / 86,60=0,461$

A51 $=40 / 86,60=0,461$

- Normalisasi matriks kriteria Kejujuran (C2)

$$
\begin{aligned}
C 2 & =\sqrt{50^{2}+50^{2}+50^{2}+50^{2}+50^{2}} \\
& =111,80
\end{aligned}
$$

$\mathrm{A} 12=50 / 111,80=0,447$

$$
\mathrm{A} 22=50 / 111,80=0,447
$$$$
\mathrm{A} 32=50 / 111,80=0,447
$$$$
\mathrm{A} 42=50 / 111,80=0,447
$$$$
\mathrm{A} 52=50 / 111,80=0,447
$$

- Normalisasi matriks kriteria Absensi (C3)

$$
\begin{aligned}
C 3 & =\sqrt{40^{2}+40^{2}+30^{2}+40^{2}+50^{2}} \\
& =90,55
\end{aligned}
$$

A13 $=40 / 90,55=0,441$

A23 $=40 / 90,55=0,441$

$\mathrm{A} 33=30 / 90,55=0,331$

$\mathrm{A} 43=40 / 90,55=0,441$

$\mathrm{A} 53=50 / 90,55=0,552$

- Normalisasi matriks kriteria Ketelitian (C4)

$$
C 4=\sqrt{40^{2}+50^{2}+50^{2}+40^{2}+30^{2}}
$$


$=95,39$

$\mathrm{A} 14=40 / 95,39=0,419$

$\mathrm{A} 24=50 / 95,39=0,524$

$\mathrm{A} 34=50 / 95,39=0,524$

$\mathrm{A} 44=40 / 95,39=0,419$

$\mathrm{A} 54=30 / 95,39=0,314$

Berdasarkan proses perhitungan diatas maka terbentuk matriks kinerja ternormalisasi, sebagai berikut:

$$
X^{*} i j=\left[\begin{array}{llll}
0,577 & 0,447 & 0,441 & 0,419 \\
0,346 & 0,447 & 0,441 & 0,524 \\
0,346 & 0,447 & 0,331 & 0,524 \\
0,461 & 0,447 & 0,441 & 0,419 \\
0,461 & 0,447 & 0,552 & 0,314
\end{array}\right]
$$

\subsection{Optimalisasi Atribut}

Proses optimalisasi atribut dilakukan dengan melihat sifat kriteria, pada penelitian ini dikarenakan sifat kriteria adalah benefit. Maka proses selanjutnya yaitu mengalikan setiap nilai alternatif pada kriteria sesuai dengan matriks kinerja ternormalisasi dengan bobot kriteria merujuk kepada Tabel 3.
$\mathrm{A} 11=0,577 * 35 \%=0,201$
$\mathrm{A} 21=0,346 * 35 \%=0,121$
$\mathrm{A} 31=0,346 * 35 \%=0,121$
$\mathrm{A} 41=0,461 * 35 \%=0,161$
$\mathrm{A} 51=0,461 * 35 \%=0,161$

$\mathrm{A} 12=0,447 * 30 \%=0,134$

$\mathrm{A} 22=0,447 * 30 \%=0,134$

A32 $=0,447 * 30 \%=0,134$

$\mathrm{A} 42=0,447 * 30 \%=0,134$

$\mathrm{A} 52=0,447 * 30 \%=0,134$

$\mathrm{A} 13=0,441 * 15 \%=0,067$

$\mathrm{A} 23=0,441 * 15 \%=0,067$

$\mathrm{A} 33=0,331 * 15 \%=0,05$

$\mathrm{A} 43=0,441 * 15 \%=0,067$

$\mathrm{A} 53=0,552 * 15 \%=0,082$ 
$\mathrm{A} 14=0,419 * 20 \%=0,083$

$\mathrm{A} 24=0,524 * 20 \%=0,104$

$\mathrm{A} 34=0,524 * 20 \%=0,104$

$\mathrm{A} 44=0,419 * 20 \%=0,083$

$\mathrm{A} 54=0,314 * 20 \%=0,062$

Hasil dari perkalian nilai alternatif setiap kriteria dengan bobot kriteria yaitu matriks normalisasi terbobot sebagai berikut:

$$
X^{*} i j=\left[\begin{array}{cccc}
0,201 & 0,134 & 0,067 & 0,083 \\
0,121 & 0,134 & 0,067 & 0,104 \\
0,121 & 0,134 & 0,05 & 0,104 \\
0,161 & 0,134 & 0,067 & 0,083 \\
0,161 & 0,134 & 0,082 & 0,062
\end{array}\right]
$$

\subsection{Menentukan Nilai Perankingan Akhir Alternatif}

Pada perhitungan nilai akhir alternatif $\left(Y_{i}\right)$, nilai alternatif pada setiap kriteria berdasarkan dari matriks normalisasi terbobot. Terdapat nilai Max dan Min dari proses perhitungan nilai akhir, merujuk kepada Tabel 3 dimana semua kriteria bersifat benefit maka hanya nilai Max yang dihitung yaitu dengan melakukan penambahan nilai setiap alternatif pada setiap kriteria. Nilai Min yaitu 0 dikarenakan tidak terdapat kriteria yang bersifat cost, kemudian pada perhitungan nilai akhir $Y_{i}$ dilakukan proses total nilai Max dikurangi nilai Min, sehingga nilai $Y_{i}$ ini menjadi nilai akhir setiap alternatif. Perhitungan nilai akhir alternatif dapat dilihat pada Tabel 9 berikut:

Tabel 9. Perhitungan Nilai Akhir Alternatif

\begin{tabular}{llll} 
Alternatif & $\begin{array}{l}\text { Max } \\
(\mathbf{C 1 + C 2 + C 3 + C 4 + C 5 )}\end{array}$ & Min & $\begin{array}{l}\mathbf{Y}_{\mathbf{i}} \\
(\mathbf{M a x}-\mathbf{M i n})\end{array}$ \\
\hline $\mathrm{A} 1$ & 0,485 & 0 & 0,485 \\
\hline $\mathrm{A} 2$ & 0,426 & 0 & 0,426 \\
\hline $\mathrm{A} 3$ & 0,409 & 0 & 0,409 \\
\hline $\mathrm{A} 4$ & 0,445 & 0 & 0,445 \\
\hline $\mathrm{A} 5$ & 0,439 & 0 & 0,439 \\
\hline
\end{tabular}

Tahap akhir yaitu melakukan perankingan nilai alternatif dari nilai terbesar sampai terkecil, nilai alternatif merujuk kepada Tabel 9. Perankingan alternatif dapat dilihat pada Tabel 10,berikut:

Tabel 10. Perankingan Alternatif

\begin{tabular}{lll} 
Alternatif & Nilai & Ranking \\
\hline A1 & 0,485 & 1 \\
\hline A4 & 0,445 & 2 \\
\hline A5 & 0,439 & 3 \\
\hline A2 & 0,426 & 4 \\
\hline A3 & 0,409 & 5 \\
\hline
\end{tabular}


Dari hasil perankingan alternatif yang merujuk kepada Tabel 10 diperoleh hasil bahwa alternatif A1 sebagai alternatif terbaik dikarenakan memperoleh nilai tertinggi yaitu 0,485 . Sehingga alternatif A1 yaitu Wawan yang paling layak menerima bonus gaji karyawan.

\section{Kesimpulan dan Saran}

Kesimpulan yang diperoleh dari penelitian ini yaitu fungsi keanggotaan Fuzzy dapat diterapkan dalam penentuan interval nilai alternatif pada setiap kriteria agar ketidakjelasan arti nilai dapat dikategorikan ke dalam fungsi keanggotaan. Proses perhitungan Metode MOORA mampu menyelesaikan permasalahan penentuan kelayakan bonus gaji pegawai dengan mempertimbangkan sifat kriteria dalam menentukan nilai akhir alternatif terbaik. Saran yang dapat diberikan untuk penelitian selanjutnya yaitu dengan mempertimbangkan penambahan kriteria sehingga hasil keputusan semakin kompleks serta pada penentuan nilai skala atribut dapat menambahkan penentuan skala metode Behaviaour Anchor Rating Scale (BARS) sehingga dapat dilakukan komparasi hasil akhir dengan nilai atribut kriteria dengan fungsi keanggotaan Fuzzy.

\section{Daftar Pustaka}

[1] I. M. D. P. Asana, I. G. I. Sudipa, and I. M. A. Wijaya, "Decision Support System For Employee Assessment At PT. Kupu-Kupu Taman Lestari Using AHP And BARS Methods: Decision Support System For Employee Assessment At PT. Kupu-Kupu Taman Lestari Using AHP And BARS Methods," J. Mantik, vol. 4, no. 1, pp. 97-106, 2020.

[2] R. M. Amalia and D. Y. Utami, "Pemberian Reward Berdasarkan Penilaian Kinerja Karyawan Dengan Metode AHP Pada PT. Anugerah Protecindo," JITK (Jurnal Ilmu Pengetah. Dan Teknol. Komputer), vol. 3, no. 2, pp. 181-188, 2018.

[3] F. Kafabih and U. Budiyanto, "Determination of Annual Employee Salary Increase and Best Employee Reward Using the Fuzzy-TOPSIS Method," in 2020 8th International Conference on Information and Communication Technology (ICoICT), 2020, pp. 1-5.

[4] I. M. D. P. Asana, I. G. I. Sudipa, and K. A. P. Putra, "A Decision Support System on Employee Assessment Using Analytical Network Process (ANP) and BARS Methods," J. Tek. Inform. CIT Medicom, vol. 13, no. 1, pp. 1-12, 2021.

[5] Y. Irawan, "Decision Support System For Employee Bonus Determination With WebBased Simple Additive Weighting (SAW) Method In PT. Mayatama Solusindo," J. Appl. Eng. Technol. Sci., vol. 2, no. 1, pp. 7-13, 2020.

[6] A. F. Boy, A. Amrullah, A. H. Nasyuha, and T. Syahputra, "E-KPI Menggunakan Metode MOORA (Multi Objective Optimization On The Basis Of Ratio Analysis) dalam menentukan Engineer yang memperoleh bonus pada CV. Arisanita," J. SAINTIKOM (Jurnal Sains Manaj. Inform. dan Komputer), vol. 19, no. 2, pp. 60-73, 2020.

[7] A. Manik, "Penerapan MOORA dalam Pedukung Keputusan Kelayakan Penerimaan Bantuan Program Keluarga Harapan (PKH)," J. Sist. Komput. dan Inform., vol. 2, no. 1, pp. 42-47, 2020. 
[8] L. Pérez-Domínguez, K. Y. S. Mojica, L. C. O. Pabón, and M. C. C. Díaz, “Application of the MOORA method for the evaluation of the industrial maintenance system," in Journal of Physics: Conference Series, 2018, vol. 1126, no. 1, p. 12018.

[9] G. Akkaya, B. Turanoğlu, and S. Öztaş, "An integrated fuzzy AHP and fuzzy MOORA approach to the problem of industrial engineering sector choosing," Expert Syst. Appl., vol. 42, no. 24, pp. 9565-9573, 2015.

[10] Z. Siddiqui and K. Tyagi, "Application of fuzzy-MOORA method: Ranking of components for reliability estimation of component-based software systems," Decis. Sci. Lett., vol. 5, no. 1, pp. 169-188, 2016.

[11] I Gede Iwan Sudipa, "Decision Support System Dengan Metode AHP, SAW dan ROC Untuk Penentuan Pemberian Beasiswa (Studi Kasus STMIK STIKOM INDONESIA)," J. Teknol. Inf. dan Komput., vol. 4, no. 1, pp. 18-30, 2018.

[12] . B. and . S., "Novelty Ranking Approach with Z-Score and Fuzzy Multi- Attribute Decision Making Combination," Int. J. Eng. Technol., vol. 7, no. 4.7, p. 476, 2018, doi: 10.14419/ijet.v7i4.7.27363.

[13] V. A. Permadi, R. P. Agusdin, S. P. Tahalea, and W. Kaswidjanti, "Identification of Student Area of Interest using Fuzzy Multi-Attribute Decision Making (FMADM) and Simple Additive Weighting (SAW) Methods (Case Study: Information System Major, Universitas Pembangunan Nasional" Veteran" Yogyakarta)," in Proceeding of LPPM UPN "Veteran" Yogyakarta Conference Series 2020-Engineering and Science Series, 2020, vol. 1, no. 1, pp. 420-428.

[14] M. L. Radhitya and G. I. Sudipa, "PENDEKATAN Z-SCORE DAN FUZZY DALAM PENGUJIAN AKURASI PERAMALAN CURAH HUJAN," SINTECH (Science Inf. Technol. J., vol. 3, no. 2, pp. 149-156, 2020.

[15] N. Dwitiyanti, N. Selvia, and F. R. Andrari, "Penerapan Fuzzy C-Means Cluster dalam Pengelompokkan Provinsi Indonesia Menurut Indikator Kesejahteraan Rakyat," Fakt. Exacta, vol. 12, no. 3, pp. 201-209, 2019.

[16] S. H. Kusumadewi, Fuzzy Multi-Attribute Decision Making (Fuzzy MADM). 2006.

[17] A. Mardani et al., "A review of multi-criteria decision-making applications to solve energy management problems: Two decades from 1995 to 2015," Renewable and Sustainable Energy Reviews. 2017, doi: 10.1016/j.rser.2016.12.053.

[18] R. K. H. Mesran, M. Syahrizal, A. P. U. Siahaan, and S. Robbi Rahim, "Student Admission Assesment using Multi-Objective Optimization on the Basis of Ratio Analysis (MOORA)," J. Online Jar. COT POLIPD, vol. 10, no. 7, 2017. 